\title{
Post-epidemic Occurrence of Bluetongue Virus Vectors (Culicoides Species) în Iași County
}

Dragoș Constantin ANIȚA ${ }^{1 *}$, Ioana Mădălina POPESCU ${ }^{1}$, Ștefania ANDERCO², Luanda Elena OȘLOBANU ${ }^{1}$, Adriana ANIȚA ${ }^{1}$, Gheorghe SAVUȚA ${ }^{1}$

${ }^{1}$ Department of Public Health, "Ion Ionescu de la Brad" University of Agricultural Sciences and Veterinary Medicine, 8 Mihail Sadoveanu Alley, Iași, Romania

${ }^{2}$ Sanitary-Veterinary and Food Safety Laboratory, 10 Mihail Sadoveanu Alley Iași, Romania

* corresponding author: danita@uaiasi.ro

Bulletin UASVM Veterinary Medicine 77(2)/2020

Print ISSN 1843-5270; Electronic ISSN 1843-5378

doi:10.15835/buasvmcn-vm:2020.0009

\begin{abstract}
Culicoides is a genus of biting midges in the family Ceratopogonidae, representing a big threat, giving that several species serve as biological vectors of pathogens of veterinary importance. BTV distribution and persistence is thought to be almost entirely dependent upon the presence or absence of Culicoides adults vector. In this study, biting midges were collected during 2015-2016, once a week, from April to December. In the first year, 2617 BTV vector specimens were collected and identified as Culicoides obsoletus (41.2\%; 95\% CI: 39-43), Culicoides pulicaris (58\%; 95\% CI: 56-59) and Culicoides nubeculosus (0.8\%; 95\% CI: 0.4-1.1). In the second year, 165 BTV vector specimens were collected and identified as Culicoides obsoletus (44.25\%; 95\% CI: 36-51), Culicoides pulicaris (50.3\%; 95\% CI: 42-57), Culicoides dewulfi (4.84\%; 95\% CI: 1.5-8.1) and Culicoides nubeculosus (0.61\%; 95\% CI: 0.5-1.7). Culicoides pulicaris and Culicoides obsoletus complex were especially abundant within the two collection sites in Iași County. Our data on post-epidemic occurrence and composition of BTV vector species in the studied area will facilitate a better understanding of Culicoides vectors distribution and the possible role in bluetongue virus overwintering.
\end{abstract}

Keywords: biting midges, Culicoides, Iași County, vectors

\section{Introduction}

Biting midges of the genus Culicoides (Diptera: Ceratopogonidae) are among the smallest hematophagous dipteran insects. These flies are of medical, veterinary, and economic importance because their blood-feeding behavior can transmit disease agents. Some species of Culicoides may act as vectors of many disease pathogens affecting livestock worldwide, including at least 66 viruses, 15 protozoa and 23 nematodes (Sick et al., 2019). Adult Culicoides are poor fliers (Mellor et al., 2000), dispersal being limited to within several kilometres from the emergence site (Kluiters et al., 2015). However, individuals can be carried over far greater distances through wind dispersal, largely inferred from the spread of Culicoides-borne disease (Gloster et al., 2008). This semi-passive flight is one of the reasons why Culicoides-borne arboviruses are capable of rapid spread (Burgin et al., 2013). Most of the Culicoidesborne viruses belong to the families Reoviridae (e.g., African horse sickness virus, bluetongue virus, or epizootic hemorrhagic disease virus), Rhabdoviridae (e.g., bovine ephemeral fever virus) and Peribunyaviridae (e.g., Akabane virus, Schmallenberg virus, or Oropouche virus). This study examines the distribution and abundance of Culicoides vectors involved in BTV transmission in Iași County, one of the counties in the eastern focus of infection of the last bluetongue epidemic. 
During this study, surveillance on biting midges was carried in two years, during 35 weeks each year.

\section{Materials and methods}

The research has been carried out during 2015-2016, once a week, from April to December in order to collect biting midges. The capture was made using modified CDC traps placed on the meadow, $1.8 \mathrm{~m}$ above the ground, in front of the stable, in the vicinity of stables with cattle. The sampling sites (Figure 1) span altitudes of $48 \mathrm{~m}$ (Vlădeni) to $62 \mathrm{~m}$ (Zaboloteni). Vlădeni collection site is located in the northeast of the county, on the shores of the Jijia river, in an area with multiple lakes. The second collection site is located also in the northeast of the Iași county, on the shores of the Prut river.

All individuals were identified in samples that contained less than 500 specimens. For the morphological identification, the Interactive IIKC key (Mathieu et al., 2012) was used for livestockassociated Culicoides species based on wing pattern and palpi. Identification was performed under a stereomicroscope with $10 \times$ and $20 \times$ magnification.

\section{Results and discussions}

Some Culicoides species (among these the most abundant being C. obsoletus) are known to act as vectors for bluetongue virus (BTV). This Orbivirus of the family Reoviridae causes an infectious disease called bluetongue disease (BTD) in ruminants - mainly sheep, but cattle and goats are affected as well.

First cases of bluetongue virus infection occurred in August 2014 in cattle, in South-East of Romania, at an altitude of 1000 meters. The animals have shown signs of disease: hyperthermia, hyperemia, congestion and erosions of the skin and mucosae, especially oral mucosa, salivation, epiphora, and nasal discharge. Forward the BTV serotype identified as BTV 4 was confirmed by the Pirbright Reference Laboratory on September 2014. In 2014, there were registered 1885 outbreaks disseminated all over the country (www. oie.int). This frequency decreased to 30 outbreaks of BTV 4 in 2015 of which three outbreaks were registered in Iași County and 18 in Botoșani County. The last outbreak of bluetongue was notified on November 2015 in the Eastern region of the country.

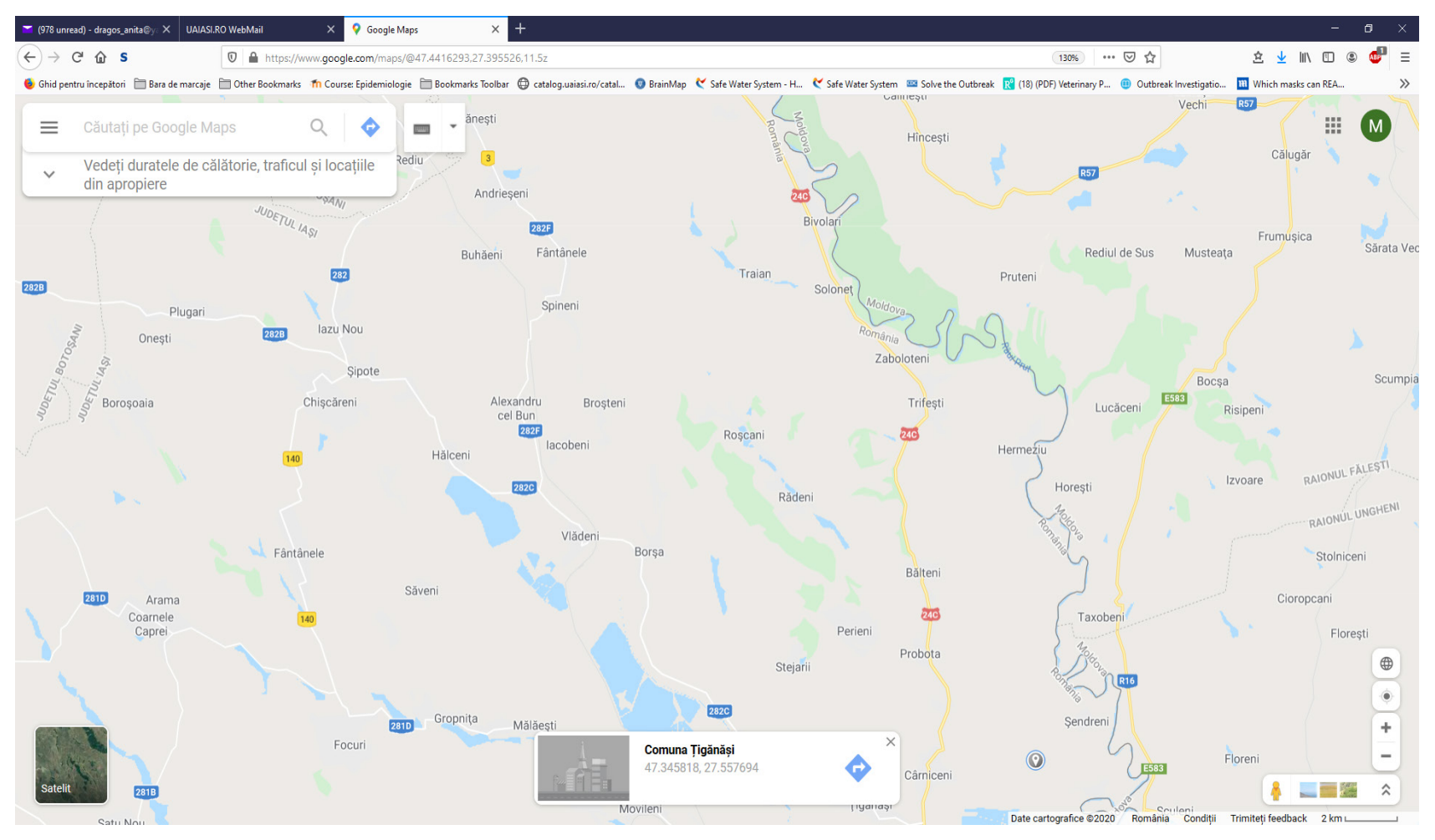

Figure 1. Geographical origin of the sampled vectors: A. in 2015; B in 2016 
On the basis of this epidemiological context of BTV4 circulation, a total of 2782 Culicoides specimens were collected during 35 consecutive weeks in each year (2015 and 2016) of the studied period. In the first year, 2617 BTV vector specimens (table 1) were collected and identified as Culicoides obsoletus (41.2\%), Culicoides pulicaris (58\%) and Culicoides nubeculosus $(0.80 \%)$.

In the second year, 165 BTV vector specimens (Table 2) were collected and identified as Culicoides obsoletus (44.25\%), Culicoides pulicaris (50.3\%), Culicoides dewulfi (4.84\%) and Culicoides nubeculosus $(0.61 \%)$.

Results of the vector monitoring carried out from 2015 to 2016, with a particular attention to the Culicoides species/complexes most involved in bluetongue virus transmission in Romania $(C$. obsoletus, C. pulicaris, C. nubeculosus, C. dewulfi), are statisticaly analized in Table 3. Culicoides pulicaris and Culicoides obsoletus complex were especially abundant within the two collection sites in Iași County.

The Culicoides pulicaris complex was most abundant, representing $57.5 \%$ of all individuals trapped, followed by the Culicoides obsoletus complex (41.5\% of individuals). The other $\mathrm{Cu}$ licoides complexes ( $C$. nubeculosus and $C$. dewulfi) represented only a very low proportion of all individuals and the major vector, $C$. imicola, was absent from all catches and sites. The maximum catch of $C$. pulicaris complex in a trap, at 1186, was two times that of the C. obsoletus complex, at 596. These two species complexes were widespread across both sites and more abundant in 2015 .

The current involvement of these two species complexes in BTV transmission in Europe is well confirmed: by fine scale overlap of their geographic distributions with outbreaks (De Liberato et al.,

Table 1. Results of the entomological surveillance performed in Iași County in 2015

\begin{tabular}{|c|c|c|c|c|c|c|}
\hline \multirow{2}{*}{ Date } & \multirow{2}{*}{$\begin{array}{c}\text { Target } \\
\text { species }\end{array}$} & \multirow{2}{*}{$\begin{array}{c}\mathrm{T}^{\mathrm{o}} \mathrm{C} \\
\min / \mathrm{max}\end{array}$} & \multirow{2}{*}{$\begin{array}{c}\text { C. obsoletus } \\
\text { No. }\end{array}$} & \multirow{2}{*}{$\begin{array}{c}\text { C. pulicaris } \\
\text { No. }\end{array}$} & \multirow{2}{*}{$\begin{array}{c}\text { C. nubeculosus } \\
\text { No. } \\
\end{array}$} & \multirow{2}{*}{$\begin{array}{c}\text { C. dewulf } \\
\text { No. }\end{array}$} \\
\hline & & & & & & \\
\hline 17.04 .2015 & bovine & $8^{\circ} \mathrm{C} / 5^{\circ} \mathrm{C}$ & 9 & 0 & 0 & 0 \\
\hline 24.04 .2015 & bovine & $12^{\circ} \mathrm{C} / 7^{\circ} \mathrm{C}$ & 3 & 1 & 0 & 0 \\
\hline 30.04 .2015 & bovine & $4^{\circ} \mathrm{C} / 7^{\circ} \mathrm{C}$ & 0 & 0 & 0 & 0 \\
\hline 06.05 .2015 & bovine & $14^{\circ} \mathrm{C} / 12^{\circ} \mathrm{C}$ & 596 & 1186 & 0 & 0 \\
\hline 13.05 .2015 & bovine & $14^{\circ} \mathrm{C} / 12^{\circ} \mathrm{C}$ & 8 & 21 & 0 & 0 \\
\hline 21.05 .2015 & bovine & $24^{\circ} \mathrm{C} / 10^{\circ} \mathrm{C}$ & 394 & 252 & 3 & 0 \\
\hline 3.06 .2015 & bovine & $24^{\circ} \mathrm{C} / 10^{\circ} \mathrm{C}$ & 6 & 4 & 0 & 0 \\
\hline 11.06 .2015 & bovine & $24^{\circ} \mathrm{C} / 18^{\circ} \mathrm{C}$ & 26 & 5 & 0 & 0 \\
\hline 24.06 .2015 & bovine & $23^{\circ} \mathrm{C} / 17^{\circ} \mathrm{C}$ & 27 & 16 & 0 & 0 \\
\hline 09.07 .2015 & bovine & $28^{\circ} \mathrm{C} / 25^{\circ} \mathrm{C}$ & 8 & 2 & 2 & 0 \\
\hline 17.07 .2015 & bovine & $24^{\circ} \mathrm{C} / 17^{\circ} \mathrm{C}$ & 0 & 0 & 0 & 0 \\
\hline 22.07 .2015 & bovine & $25^{\circ} \mathrm{C} / 18^{\circ} \mathrm{C}$ & 0 & 0 & 0 & 0 \\
\hline 30.07 .2015 & bovine & $22^{\circ} \mathrm{C} / 17^{\circ} \mathrm{C}$ & 0 & 3 & 0 & 0 \\
\hline 04.08 .2015 & bovine & $22^{\circ} \mathrm{C} / 17^{\circ} \mathrm{C}$ & 0 & 0 & 0 & 0 \\
\hline 12.08 .2015 & bovine & $22^{\circ} \mathrm{C} / 17^{\circ} \mathrm{C}$ & 0 & 0 & 0 & 0 \\
\hline$\underline{04.09 .2015}$ & bovine & $22^{\circ} \mathrm{C} / 17^{\circ} \mathrm{C}$ & 0 & 0 & 0 & 0 \\
\hline 17.09 .2015 & bovine & $20^{\circ} \mathrm{C} / 11^{\circ} \mathrm{C}$ & 1 & 8 & 8 & 0 \\
\hline 24.09 .2015 & bovine & $20^{\circ} \mathrm{C} / 11^{\circ} \mathrm{C}$ & 0 & 10 & 4 & 0 \\
\hline 09.10 .2015 & bovine & $12^{\circ} \mathrm{C} / 09^{\circ} \mathrm{C}$ & 0 & 10 & 4 & 0 \\
\hline 30.10 .2015 & bovine & $10^{\circ} \mathrm{C} / 5^{\circ} \mathrm{C}$ & 0 & 0 & 0 & 0 \\
\hline 09.11 .2015 & bovine & $9^{\circ} \mathrm{C} / 2^{\circ} \mathrm{C}$ & 0 & 0 & 0 & 0 \\
\hline 12.11 .2015 & bovine & $9^{\circ} \mathrm{C} / 2^{\circ} \mathrm{C}$ & 0 & 0 & 0 & 0 \\
\hline 19.11 .2015 & bovine & $9^{\circ} \mathrm{C} / 2^{\circ} \mathrm{C}$ & 0 & 0 & 0 & 0 \\
\hline \multicolumn{3}{|c|}{ Total } & 1078 & 1518 & 21 & $\mathbf{0}$ \\
\hline
\end{tabular}


2005), by vector competence studies (Paslaru et al., 2018; Carpenter et al., 2006) and by virus isolation from wild-caught adults of C. pulicaris and C. obsoletus complex (Savini et al., 2005). Climate change has been implicated in the spread of BTV vectors in Europe, with an increasing incidence of BTV outbreaks in areas that have warmed over the last decade. A cross-sectional study demonstrated

Table 2. Results of the entomological surveillance performed in Iași County in 2016

\begin{tabular}{|c|c|c|c|c|c|c|c|}
\hline \multirow{2}{*}{ Date } & \multirow{2}{*}{$\begin{array}{c}\text { Target } \\
\text { Species }\end{array}$} & \multirow{2}{*}{$\begin{array}{c}\mathrm{T}^{\mathrm{o}} \mathrm{C} \\
\min / \max \end{array}$} & \multirow{2}{*}{$\begin{array}{c}\text { C. obsoletus } \\
\text { No. }\end{array}$} & C.pulicaris & \multirow{2}{*}{$\begin{array}{c}\text { C. nubeculosus } \\
\text { No. } \\
\end{array}$} & \multirow{2}{*}{$\begin{array}{c}\text { C. dewulfi } \\
\text { No. } \\
\end{array}$} & \multirow{2}{*}{$\begin{array}{c}\text { C.imicola } \\
\text { No. } \\
\end{array}$} \\
\hline & & & & No. & & & \\
\hline 07.04 .2016 & bovine & $23^{\circ} \mathrm{C} / 10^{\circ} \mathrm{C}$ & 10 & 1 & 0 & 0 & 0 \\
\hline 14.04 .2016 & bovine & $23^{\circ} \mathrm{C} / 10^{\circ} \mathrm{C}$ & 10 & 72 & 0 & 0 & 0 \\
\hline 22.04 .2016 & bovine & $11^{\circ} \mathrm{C} / 8^{\circ} \mathrm{C}$ & 0 & 0 & 0 & 0 & 0 \\
\hline 22.04 .2016 & bovine & $11^{\circ} \mathrm{C} / 8^{\circ} \mathrm{C}$ & 0 & 0 & 0 & 0 & 0 \\
\hline 28.04 .2016 & bovine & $14^{\circ} \mathrm{C} / 6^{\circ} \mathrm{C}$ & 0 & 1 & 0 & 0 & 0 \\
\hline 05.05 .2016 & bovine & $13^{\circ} \mathrm{C} / 14^{\circ} \mathrm{C}$ & 1 & 1 & 1 & 0 & 0 \\
\hline 12.05 .2016 & bovine & $13^{\circ} \mathrm{C} / 14^{\circ} \mathrm{C}$ & 0 & 0 & 0 & 0 & 0 \\
\hline 25.05 .2016 & bovine & $15^{\circ} \mathrm{C} / 16^{\circ} \mathrm{C}$ & 3 & 0 & 0 & 0 & 0 \\
\hline 30.05 .2016 & bovine & $23 \mathrm{C} / 16 \mathrm{C}$ & 0 & 0 & 0 & 0 & 0 \\
\hline 03.06 .2016 & bovine & $15^{\circ} \mathrm{C} / 16^{\circ} \mathrm{C}$ & 0 & 0 & 0 & 0 & 0 \\
\hline 10.06 .2016 & bovine & $15^{\circ} \mathrm{C} / 16^{\circ} \mathrm{C}$ & 0 & 0 & 0 & 0 & 0 \\
\hline 17.06 .2016 & bovine & $25^{\circ} \mathrm{C} / 18^{\circ} \mathrm{C}$ & 0 & 0 & 0 & 0 & 0 \\
\hline 22.06 .2016 & bovine & $28^{\circ} \mathrm{C} / 23^{\circ} \mathrm{C}$ & 8 & 5 & 0 & 3 & 0 \\
\hline 23.06 .2016 & bovine & $25^{\circ} \mathrm{C} / 18^{\circ} \mathrm{C}$ & 2 & 1 & 0 & 0 & 0 \\
\hline 30.06 .2016 & bovine & $25^{\circ} \mathrm{C} / 20^{\circ} \mathrm{C}$ & 0 & 0 & 0 & 0 & 0 \\
\hline 07.07 .2016 & bovine & $25^{\circ} \mathrm{C} / 20^{\circ} \mathrm{C}$ & 9 & 1 & 0 & 2 & 0 \\
\hline 13.07 .2016 & bovine & $26^{\circ} \mathrm{C} / 19^{\circ} \mathrm{C}$ & 27 & 0 & 0 & 3 & 0 \\
\hline 14.07 .2016 & bovine & $27^{\circ} \mathrm{C} / 18^{\circ} \mathrm{C}$ & 0 & 0 & 0 & 0 & 0 \\
\hline 22.07 .2016 & bovine & $27^{\circ} \mathrm{C} / 18^{\circ} \mathrm{C}$ & 0 & 0 & 0 & 0 & 0 \\
\hline 28.07.2016 & bovine & $27^{\circ} \mathrm{C} / 21^{\circ} \mathrm{C}$ & 1 & 1 & 0 & 0 & 0 \\
\hline$\underline{05.08 .2016}$ & bovine & $27^{\circ} \mathrm{C} / 18^{\circ} \mathrm{C}$ & 1 & 0 & 0 & 0 & 0 \\
\hline 11.08 .0216 & bovine & $27^{\circ} \mathrm{C} / 14^{\circ} \mathrm{C}$ & 0 & 0 & 0 & 0 & 0 \\
\hline 18.08 .2016 & bovine & $27^{\circ} \mathrm{C} / 18^{\circ} \mathrm{C}$ & 0 & 0 & 0 & 0 & 0 \\
\hline 23.08 .2016 & bovine & $27^{\circ} \mathrm{C} / 19^{\circ} \mathrm{C}$ & 0 & 0 & 0 & 0 & 0 \\
\hline 25.08 .2016 & bovine & $26^{\circ} \mathrm{C} / 15^{\circ} \mathrm{C}$ & 0 & 0 & 0 & 0 & 0 \\
\hline 01.09 .2016 & bovine & $26^{\circ} \mathrm{C} / 13^{\circ} \mathrm{C}$ & 1 & 0 & 0 & 0 & 0 \\
\hline 08.09 .2016 & bovine & $28^{\circ} \mathrm{C} / 15^{\circ} \mathrm{C}$ & 2 & 1 & 0 & 0 & 0 \\
\hline 14.09 .2016 & bovine & $27^{\circ} \mathrm{C} / 14^{\circ} \mathrm{C}$ & 2 & 1 & 0 & 0 & 0 \\
\hline 22.09 .2016 & bovine & $16^{\circ} \mathrm{C} / 5^{\circ} \mathrm{C}$ & 0 & 0 & 0 & 0 & 0 \\
\hline 12.10 .2016 & bovine & $8^{\circ} \mathrm{C} / 8^{\circ} \mathrm{C}$ & 0 & 0 & 0 & 0 & 0 \\
\hline \multicolumn{3}{|c|}{ Total } & 73 & 83 & 1 & 8 & $\mathbf{0}$ \\
\hline
\end{tabular}

Table 3. The aboundance of Culicodes species in the two colections sites from Iași County

\begin{tabular}{|c|c|c|c|c|c|c|c|c|}
\hline \multirow[b]{2}{*}{ Sampling year } & \multicolumn{2}{|c|}{ C. obsoletus } & \multicolumn{2}{|c|}{ C. pulicaris } & \multicolumn{2}{|c|}{ C. nubeculosus } & \multicolumn{2}{|c|}{ C. dewulfi } \\
\hline & No. & $\begin{array}{c}\text { Prevalence } \\
\text { (CI 95\%) }\end{array}$ & No. & $\begin{array}{c}\text { Prevalence } \\
\text { (CI 95\%) }\end{array}$ & No. & $\begin{array}{c}\text { Prevalence } \\
\text { (CI 95\%) }\end{array}$ & No. & $\begin{array}{c}\text { Prevalence } \\
\text { (CI 95\%) }\end{array}$ \\
\hline 2015 & 1078 & $\begin{array}{c}41.2 \% \\
(39-43)\end{array}$ & 1518 & $\begin{array}{c}58 \% \\
(56-59)\end{array}$ & 21 & $\begin{array}{c}0.8 \% \\
(0.4-1.1)\end{array}$ & 0 & 0 \\
\hline 2016 & 73 & $\begin{array}{l}44.25 \% \\
(36-51)\end{array}$ & 83 & $\begin{array}{c}50.3 \% \\
(42-57)\end{array}$ & 1 & $\begin{array}{c}0.6 \% \\
(-0.5-1.7)\end{array}$ & 8 & $\begin{array}{c}4.84 \% \\
(1.5-8.1)\end{array}$ \\
\hline
\end{tabular}


that Culicoides vectors are active during peak delivering periods inside sheds. A longitudinal study the following delivery season demonstrated that Culicoides were more abundant indoors than outdoors, and demonstrated activity of gravid and parous Culicoides over the winter (Magliano et al., 2018). This demonstrates a possible mechanism for overwintering of BTV4 in the east of Romania during 2014-2015.

\section{Conclusions}

The Culicoidesabundance analysed in this study is exclusively based on the abundance observed on cattle farms. BTV distribution and persistence is thought to be almost entirely dependent upon the presence or absence of Culicoides adults vector. Thus, our data on post-epidemic occurrence and composition of BTV vector species in the studied area is the first step for a better understanding of Culicoides vectors distribution and the possible role in virus overwintering. Further indepth studies are to be undertaken in order to conclude if there is still a risk of BTV or other Culicoides transmitted diseases in Iași County.

Acknowledgments. This research did not receive any specific grant from funding agencies in the public, commercial, or not-for-profit sectors.

\section{References}

1. Burgin LE, Gloster J, Sanders C, Mellor PS, Gubbins S, Carpenter S (2013). Investigating incursions of bluetongue virus using a model of longdistance Culicoides biting midge dispersal. Transbound and Emerg Dis, 60(3):263-272. doi: 10.1111/j.1865-1682.2012.01345.x

2. Carpenter S, Lunt HL, Arav D, Venter GJ, Mellor PS (2006). Oral susceptibility to bluetongue virus of Culicoides (Diptera: Ceratopogonidae) from the United Kingdom. J Med Entomol, 43(1)73-78. doi:10.1093/jmedent/43.1.73

3. De Liberato C, Scavia G, Lorenzetti R, Scaramozzino P, Amaddeo D, Cardeti G, Scicluna M, Ferrari G, Autorino GL (2005). Identification of Culicoides obsoletus (Diptera: Ceratopogonidae) as a vector of bluetongue virus in central Italy. Vet Rec, 156(10):301-304. doi: 10.1136/ vr.156.10.301

4. Gloster J, Burgin L, Witham C, Athanassiadou M, Mellor PS (2008). Bluetongue in the United Kingdom and northern Europe in 2007 and key issues for 2008. Vet Rec 162(10):298-302. doi: 10.1136/vr.162.10.298

5. Interactive Identification Key for Culicoides (Diptera: Ceratopogonidae) Females From the Western Palaearctic Region (2015). URL http://www.iikculicoides.net/

6. Kluiters G, Swales H, Baylis M (2015). Local dispersal of palaearctic Culicoides biting midges estimated by markrelease-recapture. Parasit Vectors, 8:86. doi:10.1186/ s13071-015-0658-z

7. Magliano A, Scaramozzino P, Ravagnan S, Montarsi F, Rold DA Cincinelli G, Moni A, Silvestri P, Carvelli A, Liberato DE, (2018). Indoor and outdoor winter activity of Culicoides biting midges, vectors of bluetongue virus, in Italy. Med Vet Entomol, 32(1):70-77. doi:10.1111/mve.12260

8. Mathieu B, Cêtre-Sossah C, Garros C, Chavernac D, Balenghien T, Carpenter S, Setier-Rio ML, Vignes-Lebbe R, Ung V, Candolfi E, Delécolle JC (2012). Development and validation of IIKC: an interactive identification key for Culicoides (Diptera: Ceratopogonidae) females from the Western Palaearctic region. Parasit Vectors, 5:137. doi https://doi.org/10.1186/1756-3305-5-137.

9. Mellor PS, Boorman J, Baylis M (2000). Culicoides biting midges: Their role as arbovirus vectors. Annu Rev Entomol, 45:307-340. doi: 10.1146/annurev.ento.45.1.307.

10. Paslaru AI, Mathis A, Torgerson P, Veronesi E (2018). Vector competence of pre-alpine Culicoides (Diptera: Ceratopogonidae) for bluetongue virus serotypes 1, 4 and 8. Parasit Vectors, 11(1):466. doi:10.1186/s13071-0183050-y.

11. Savini G, Goffredo M, Monaco F, Di Gennaro A, Cafiero MA, Baldi L, de Santis P, Meiswinkel R, Caporale V (2005). Bluetongue virus isolations from midges belonging to the Obsoletus complex (Culicoides, Diptera: Ceratopogonidae) in Italy. Vet Rec, 157(5):133-139. doi: 10.1136/ vr.157.5.133

12. Sick F, Beer M, Kampen H, Wernike K (2019). Culicoides Biting Midges-Underestimated Vectors for Arboviruses of Public Health and Veterinary Importance. Viruses, 11(4):376. doi:10.3390/v11040376.

13. World Organisation for Animal Health. Self-declaration by Romania on regaining its Bluetongue free status (2018). URL https://www.oie.int/fileadmin/Home/eng/Animal_ Health_in_the_World/docs/pdf/Self-declarations/BTV_ Romania_selfdeclaration_EN.pdf 